\title{
The Impact of Supportive Work Environment, Trust, and Self-Efficacy on Organizational Learning and Its Effectiveness: A Stimulus-Organism Response Approach
}

\author{
Saman Attiq ${ }^{1}$, Hassan Rasool' ${ }^{2}$, Shahid Iqbal ${ }^{3}$
}

\begin{abstract}
This study examines the relationship among management and peer support, trust, self-efficacy, organizational learning, and organizational effectiveness. Within organization, supportive work environment plays a significant role in the establishment of employees' learning process. The causal design is used to analyze the impact of supportive work environment on employees' psychological influence (i.e. trust and self-efficacy) and organizational learning. The nature of the study is cross-sectional with convenience sampling technique. Data is collected from employees of 400 banks located at twin cities i.e. Islamabad and Rawalpindi through self-administered questionnaire. Data was analyzed through Structural Equation Modeling (SEM) through maximum likelihood. Finding indicates that top-management and co-worker support (i.e. stimulus) had significant positive impact on employee's trust and self-efficacy (i.e. organism) and organism acts as mediator between stimulus and response. Moreover, employees' trust (cognitive/emotional), and self-efficacy had significant positive impact on organizational learning and organizational effectiveness (i.e. response). Bank managers, industry associations, training providers, and research institutions may use findings to bring improvements in organizational learning mechanisms and employee behaviors to enhance the overall effectiveness of the organizations.
\end{abstract}

Keywords: Organizational effectiveness, organizational learning, emotional trust, cognitive trust, self-efficacy, management support

\section{Introduction}

Learning organizations evolve owing to the learning and behavior of their em-

1 Assistant Professor, Department of Management Sciences, University of Wah, Wah Cantt. Email: dr.saman.attiq@uow.edu.pk

2 Assistant Professor, Pakistan Institute of Development Economics (PIDE).Email: rasool.hassan@ gmail.com

3 MS Scholar, National Defense University, Islamabad. Email: shahid_pak1@yahoo.co.uk

\begin{tabular}{lll} 
ARTICLE HISTORY & & \\
19 Oct, 2016 Submission Received & 13 Nov, 2016 & First Review \\
\hline 18 Dec, 2016 Revised Version Received & 29 Jan, 2017 & Second Review \\
\hline 13 Feb, 2017 Revised Version Received & 25 Feb, 2017 & Accepted
\end{tabular}


ployees. The individuals therefore form the first block of the learning process, which ultimately leads to the building of learning process in the learning organization. A Learning Organization (LO) is 'an organization which is capable of acquiring, creating, and transferring knowledge, and modifying its behavior to reflect new knowledge and insights' (Garvin, 1993, p.80).

The understanding of organizational learning is thus incumbent upon comprehending the individual learning process so that LOs can focus primarily on management, valuing and enhancing the development of its employees (Scarbrough, Swan, \& Preston, 1999). Organizational learning is a cross cutting, multilayered, and evolving process which comprises behavioral, cognitive, and social elements. Whereas, the primary element of measurement of learning is the organization itself, however, organizational learning depends upon the incumbency of the organization to facilitate the learning of its members (staff, management, leadership) and by default continuously transforming itself.

The knowledge based economy lays premium on intellectual capabilities of the organizations rather than physical input or natural resources. In the intensely competitive global market, organizations strive to maintain competitive advantage over their rivals through a well-integrated and knowledge equipped forces. Towards this end, there is a marked shift from individual learning towards organizational learning for increased productivity and enhanced output. Defined as 'Knowledge Acquisition', the learning process involves generating, sharing, evaluation and combination of knowledge by the members (Argote, 2012). Organizations learning (LO) is defined as those organizations which continuously transform themselves through the continuous facilitation of its members and is built upon the level of individuals (Gilson, Dunleavy, \& Tinkler, 2009) in which the learning process involves setting expectations, creating a supportive culture, and structuring the improvement efforts such as learning effectiveness (Nembhard \& Tucker, 2016). Since the success of an organization is built upon the cumulative efforts of the individual members, the organization and individual learning hence contribute towards the overall success of the organization (Goyal \& Chhabra, 2016). Learning in an organization is therefore the edifice on which the organization builds and sustains competitive advantage (King, 2009).

The organizations and service sector must therefore be constantly in a 'knowing' and 'learning' mode to survive and adopt relentless challenges of the evolving market. Seen in this background, the constant evolving nature of the global economy makes it incumbent upon organizations to be proactive in developing LO initiatives (Alaei, Shafaee, Ariana, \& Maghvan, 2012). Rather than waiting for the experience to accumulate for organizational learning, the rapid pace of technological innovation in most industries has made it imperative on organizations to learn at a faster rate. Resultantly, 
scholars and practitioners have started to shift their focus from autonomous learning to deliberate learning. An effort is therefore being made by management researchers to better understanding drivers of successful organizational learning (Lapré \& Nembhard, 2011). Research in this direction has been focused on determining the effects of learning versus execution, effective learning activities, conditions that support learning, and what organizations engaged in learning efforts can expect (Hunt et al., 2015; Nembhard, Cherian, \& Bradley, 2014).

Delivery of superior services to customers particularly in the banking sector acts as a water shed in differentiating a brand in the intense inter banking rivalry in the market, resulting into boosting of the image of the organization, which would lead to a higher market share (Yavas \& Benkenstein, 2007). The in-role performance of the employees is determined through their attitude with actively disengaged employees displaying poor work performance, which incur substantial cost to the organization (Soni, 2013). Organizations need better equipped and more trained employees in new product/services development and other related functions. However, it still remains ambiguous as to which types of capabilities are best suited to develop in individuals to fit this purpose (Anderson, Potočnik, \& Zhou, 2014)

A constant effort to achieve competitive advantage needs zealous, proficient and highly encouraged workers who perform proficiently and are able to use new information in their working environment. Competitive advantage can only be based on better management of employees and $\mathrm{LO}$ cause the organizational performance to meet the competitive advantage for long term (Afzali, Motahari, \& Hatami-Shirkouhi, 2014). If the organization supports the employees e.g. through training and skill development, they would develop the organization that would result as organizational development or effectiveness (Goyal \& Chhabra, 2016). Therefore, the organizations have learnt the importance of supporting work environment (Arnold \& Dupré, 2012).

The study explores the supportive work environment with organizational learning in the banking industry because banking industry is highly exposed to competition and smart bank managers realize that providing better customer services can differentiate their brand from the competition. Delivery of better services can promote their image and may cause an increase in their market share (Yavas \& Benkenstein, 2007). Similarly, the attitudes of bank employees may help in determining their in-role performance (Wallace, de Chernatony, \& Buil, 2011) and actively engaged employees help in declining the substantial tangible costs (Soni, 2013). According to Birdi, Leach, and Magadley (2012) employee support through learning or training programs impact on organizational performance and organizations require more refined employees for improved services, but the mechanism for desired capabilities of employees that satisfies this purpose is yet unclear (Anderson et al., 2014) 
Similarly, organizational support as part of supporting work environment develop trust for the organization and self-efficacy get capable as source of organizational success (Miao, 2011). However, the study of Atak and Erturgut (2010) found significant relation between organizational support and OL through commitment. Similarly, Afzali et al. (2014) found the indirect relationship between organizational support and learning organization. Managers who have the wherewithal to learn effectively and to use their managerial role in an efficient way would be able to enhance and develop the employee's learning capability. This in return boosts organizational effectiveness Organizational and leads to enhanced performance via better knowledge, resulting into an improved effective behavior. In today's competitive environment, employees' trust is a key concern of most of the organizations for achieving competitive advantage. The environment of trust doesn't happen at once in any organization, rather it is deliberately nurtured. It goes beyond doubt that trust is vital for information sharing between employees. However, the nature of trust is not only complex but also challenging to comprehend as it is thought to have different facets which have different impacts on sharing of knowledge between individuals (Chowdhury, 2005). Thus, the organizational learning cannot be attained without trust (Anbar \& Eker, 2016).

Additionally, individual employee might possibly obtain task related information plus expertise from his/her colleague in term of support that may help in making new ways in order to do things possible. Sometimes, employees are hesitant towards learning due to lack of trust in learning or they think that they will miss out on work time, which may delay the completion of their assignments which in turn may antagonize their supervisors. In this context, a supportive work environment can play an important role in effective learning for sub-ordinates. The employees' perception of their respect and care through supportive work environment results the high job performance (Oh et al., 2014).

Moreover, the literature posits the interest of researchers in establishing numerous links between employees perspective and 'Employees' attitudes' (Wallace et al., 2011), 'Perceived ethical climate' (Karatepe \& Agbaim, 2012), 'Perceived Organizational support and service recovery performance'(Karatepe, 2012), 'job embeddedness and creative performance'(Karatepe \& Vatankhah, 2014), 'High-performance work practices such as training in the work environment (Karatepe, 2015), leads positive employee outcomes (Ohme \& Zacher, 2015) and work engagement (Karatepe, 2016) to conduct research in exploring the impact of high performance work practices as organizational support with organizational outcome. Similarly, Birdi et al. (2012) explored the environmental support and individual capabilities along-with various dimensions of innovative behavior.

The study of Egan, Yang, and Bartlett (2004) suggests exploring for organizational 
learning and organizational performance outcome with organizational support as they are less explored. Researchers confess that they have ignored the underlying mechanism that builds these connections, hence emphasize the need for exploring knowledge and skills and abilities with organizational support (Messersmith, Patel, Lepak, \& Gould-Williams, 2011). The studies of Karatepe (2015) and Shen, Li, and Yang (2015) explored the mediation gap between management support and performance, whereas, Chauhan, Ghosh, Rai, and Shukla (2016) suggest exploring management support and opportunity to practice on transfer of training. Similarly, numerous researchers have suggested working on peer/ supervisor support and organizational skills(Birdi, Leach, \& Magadley, 2016; Çokpekin \& Knudsen, 2012); Further, it is also suggested that the organisational and individual factors link to working/practice environments (AbuAlRub, Al-Akour, \& Alatari, 2015; Fallatah \& Laschinger, 2016; Numminen, Leino-Kilpi, Isoaho, \& Meretoja, 2015) and organizational learning and its implementation (Nembhard \& Tucker, 2016) can be viewed in the required missing mechanism. Hence, this study aims to fill these gaps and contribute to the existing literature on these issues in addition to improving the understanding of the managers, behaviorists, academicians and policy makers. Major research question of this study is how does work environment stimulate employees' cognitive process of organizational learning in terms of the Stimulus-Organism-Response (S-O-R) model in the formation of learning effectiveness? This question can be further broken down in two sub-questions, (i) what is the role of supportive work environment (i.e. management support and peer support) and employee's cognitive/internal factors (i.e. trust and self-efficacy) in the development of organizational learning? And (ii) how does employees' organizational learning persuade them in the creation of learning effectiveness?

\section{Literature Review}

\subsection{Supportive Work Environment}

Work environment and external social environment are added sources of critical influence on employees' creativity and innovation (Çokpekin \& Knudsen, 2012). Innovative work behavior and perceived departmental support of the employees, both are strongly influenced by environment (Birdi, 2007). Furthermore, (Evanschitzky, Eisend, Calantone, \& Jiang, 2012) found that both organizational climate and top management support significantly predict new goods (product/service) success. The fact that investment in human resources is a panacea for gaining competitive advantage has been verified. This competitive advantage in learning organization in the shape of developing learning effectiveness and management capability is gained by organizations through investment of billions of dollars in management development 
programs. Learner characteristics, learning culture, learners' ability, and support at work or work environment have been proved by a number of researcher to be the significant factors of 'Learning Transfer System Inventory framework' (Holton, Bates, \& Ruona, 2000). The sources of support at work identified by Blume, Ford, Baldwin, and Huang (2010) includes; peer support, subordinate support, supervisors' support, and senior management support.

\subsubsection{Peer support}

In learning organization, basically, both supervisor and peer support influence transfer of training, they effect motivation to learn and further, the skill transferring through information-sharing with peers and networking has found to be more than the knowledge transfer accrued through supervisors' influence (Bates, Holton, \& Hatala, 2012). The environment conducive for transfer of knowledge is created both through supervisor as well as peer support (Lau \& McLean, 2013). The efficacy of supervisor support for affecting learning has been established through numerous studies, both in the domain of empirical as well as qualitative studies (Blume et al., 2010).

Extant of literature has corroborated that managers' support, besides emotional, peer and informational support plays a great role in gaining and transferring of knowledge (Choi \& Chang, 2009). Moreover, in transfer of training or in learning, co-workers exhibit a key role rather than supervisor support in learning or transfer of training (Chauhan et al., 2016). The current study therefore focuses exclusively on peer support, marginalizing the supervisor support since both forms of support have significant impact on learning and extensive literature on supervisor support readily available.

\subsubsection{Subordinate support}

The subordinates' support can be better comprehended through the level of trust the subordinates repose in their supervisors and management (Findikli, Gulden, \& Semercioz, 2010. Contrarily, supervisor support for training transfer denotes the degree of support the employees receive for improving their knowledge and developing their skills at job (Wei Tian, Cordery, \& Gamble, 2016). Supervisors, subordinates and peer support is often interpreted as signals of support from workers and the recognition of the institution (Hui, Lee, \& Rousseau, 2004). Besides the social support available for the transfer of skilled behavior, a host of available social support include top management, supervisors, peers, and subordinates (Noe, 1986). An inquiry of the training literature proffers that these host of possible significant sources of social support for training may have differential effects on significant training outcomes. The exploration of the factors that affect the effective transfer of the training by su- 
pervisors, employees and peers posit consistently better outcomes provided by these associations (Martin, 2010). The valuable effect of these interpersonal support for training transfer in literature has also been conventionally observed in relations to its supporting impact on employees' task performance (Shantz \& Latham, 2012).

Likewise, the social support measures may also impinge the motivation level in these enumerated relationships. Lack of trust of the employees in the positive feedback of training due to either non-supportive peers, subordinates, supervisors, management, or a lack of resources, would result into diminished motivation for attending and learning from training. Resultantly, an employee endowed with great opportunities to practice and apply the knowledge, skills and abilities acquired through training valuable to their supervisor or given constructive feedback on their efforts to transfer from their employees tend to perform better than someone who remained deprived from such help.

\subsubsection{Supervisor and management support}

In the ongoing debate on the efficacy of various types of supports on transfer of knowledge, (Dermol \& Čater, 2013) opine that management support get preeminence for transfer of knowledge since management has ability and authority to impact the quantity and quality of training. Peer support on the other hand is not as critical as management support owing to the trainees' perception of peers being devoid of possessing any influence in determining the quantity or quality of training as well as peers' inability to decide on helpful rewards for transfer of training. Advocating the importance of management support, (Hawley \& Barnard, 2005) have extolled that in the absence of management support, the influence of peer support tends to diminish.

On the other hand, Chiaburu, Van Dam, and Hutchin (2010) have eulogized the preeminence of peer support on transfer over supervisor and organizational support. Conversely, it has established that contrary to organizational and supervisor support, only peer support is significantly associated to transfer (Homklin, Takahashi, \& Techakanont, 2014). Hinno (2012) has inscribed that supportive management is the primary factor in practice environment. The supportive management along with positive practice environment promotes employees' professional autonomy, increase their professional competence and leads to optimization of performance, resulting into positive outcome for the organization (Kirwan, Matthews, \& Scott, 2013). Since the establishment of preeminence of the type of the support required for transfer of knowledge/ learned skills to workplace, whether management or peers' support is a difficult proposition keeping in view the extant of literature on the subject, this study would therefore focus only on management and peer support. 


\subsection{Trust}

Trust has been defined as a "psychological state in which one accepts being vulnerable in positive expectation of the intentions and actions of another person" (Rousseau, Sitkin, Burt, \& Camerer, 1998). The established measures of trust have focused specific relations between individuals working across organizations, between managers (cognition-and affect-based trust), and between collective entities (departments), and across vertical relations (McEvily \& Tortoriello, 2011). Trust has also been described as the willingness of a party to be at risk which consequently depends on the actions of other party and social welfare rather than their own self-interest. Martinez and Zeelenberg (2015) describe the trust as belief to act for social welfare rather than personal interest. Trust plays critical role in building foundation of cooperation with management and employees and employees get involved in sharing and implementing their knowledge (Reina \& Reina, 2006). Trust between supervisor and subordinates play an important mentoring role in an organization, it benefits the mentee, and eventually enhances mentee's performance in an organization. The fair treatment and support of management develop the environment of trust ( $\mathrm{Lu}, 2014)$. Trust is explored with organizational learning in the study of Anbar and Eker (2016).

Therefore, better management always care about building and repairing emotional trust because the trust is always build upon trust (Kamena \& Potter, 2016). Trust is defined as cognitive trust that includes capability, skill and accountability etc. Whereas emotional trust is related to social trust that takes place with an emotional supposition and both help in achieving organizational objectives by positively influencing exchange of knowledge among employees (Levin \& Cross, 2004). So, it can be proposed that cognitive trust in integrity impacts organizational learning.

\subsection{Self-Efficacy}

Self-efficacy is self-assessment of one's ability to effectively perform a course of action required to reach coveted outcomes. A type of vital internal resource, self-efficacy refers to "people's judgments of their capabilities to organize and execute the courses of action required attaining designated types of performances" (Bandura, 1986). Self-efficacy effects the tasks employees decide to learn and helps in setting the objectives for themselves. It also has an impact on employee's determination and effort while learning challenging jobs (Lunenburg, 2011). Individuals with high self-efficacy exert more effort to their intended future activities. Individuals having amplified self-efficacy are believed to have high levels of commitment, performance, task orientation and creativity (Tierney \& Farmer, 2002).

Basically, the concept of self-efficacy describes the individual's behavior as result 
of interaction between individuals' traits and work environment. Self-efficacy influences individual's learning ability that enable them to perform only perceived focal tasks with the intention of enhanced organizational learning (Hayati, Charkhabi, \& Naami, 2014) declared multi job characteristics such as authority for budding motivation for self-efficacy. Observing self-efficacy on personal level, it also has impact on employee's determination and effort while learning challenging jobs (Lunenburg, 2011). Employees with high self-efficacy do not give up and try to solve the problems and are less likely to resign from desired goals (Charkhabi, Abarghuei, \& Hayati, 2013). Similarly, these people consider obstacles as opportunities rather than threats (Manojlovich, 2005), therefore, they show higher professional commitment (Tsai et al., 2014). Self-efficacy has been found to mediate the relationship between work engagement and leader behavior while explaining the intrinsic motivational processes (Mache et al., 2014).

\subsection{Organizational Learning and Effectiveness}

According to Cameron (1978), organizational effectiveness is ability of the organization to have an access to the necessary resources. Literature enumerates that organizational learning consists of ontological dimensions at two levels, i.e. individual and collective. According to most researchers organizational learning is product of involvement by organizational members individually and as group in the communication and sharing of knowledge and expertise (Shafritz \& Ott, 2001).

Organizational learning serves as umbrella to organizational theories that deal with knowledge accusation and learning (Morgen, 1997). Two things that determine organizational effectiveness such as 'the alignment of internal (task) environment of an organization and institutional environment which helps in setting context for overall profitability of an industry' (Hirsch, 1975). Learning program or training has proved to have a major impact on organizational performance and its effectiveness (Birdi et al., 2012). Different researchers have argued that organizational learning facilitates towards achieving effectiveness and constant development of an organizations with the help of procedures and systems of learning (Hines, 2008).

Since, learning is denoted as "reflective change", it implies that the omnipresent cognitive component to learning leads to creation of new assumptions, new causal relationships, and changes in the cognitive associations and interpretative schemes between the members of an organization. The individual's learning theories have a substantial bearing on the concept of organisational learning. With the significant impact of individual learning on the practices and concept of organizational learning, the individual learning in conceptual framework has mostly been delineated through a number of theories which purport to wide array of learning models. These theories 
include; Social Cognitive Theory (SCT), Cognitive Theory (CT), and Behavioral Theory (BT) etc.

The responsive learning is expounded by the cognitive theory which enumerate that occurrence of learning is contingent upon cueing of certain cognitive associated with the choice point may ultimately lead to a reward or a goal and purposeful learning is denoted by the social learning theory, while behavioural theory posits reactive learning (Luthans, 1998). The cited assertion clearly amplifies that learning and cognition are intertwined and interlinked, learning requiring cognition and cognition involving learning, the cognitive process resulting into acquisition of learning (Huber, 1991). Integrating both social and cognitive processes, SCT endeavors to comprehend action, emotions and motivation. Conceptualized by Bandura (1986), Stimulus - Organism model, a typical social cognitive model mediates cognitive processes - response. However, the remaining theories also contribute to the current practices of organizational learning, with all theory having its specific emphasis on the learning process such as self-efficacy that is the focus of the SCT.

Notwithstanding the above assertion, Curado (2006) propagated individual learning to be a cognitive process in its essence, whereas organizational learning to be generally a social process. Forgoing in view, if the process of organizational learning is viewed as mainly a social and cognitive process, it brings to the fore conclusion that organizational learning can be regarded as a process in itself. Therefore, it is worth realizing that the above-mentioned influences need to be investigated together in order to examine their interplay and to analyze their contribution towards cognitive process of organizational learning towards organizational effectiveness.

\subsection{Social Cognitive Theory (SCT)}

Put simply, majority of social learning theorists had been interested more primarily in 'processes of individual rational learning (Miller \& Dollard, 1941). The dominance of cognitivists was highlighted due to identification and significance of the influence of individual's internal characteristics along with the environmental/external factors in decision process and behavior formation(Furedy \& Riley, 1987). Actually, SCT purposes that individuals learn through the interaction of their environment with personal characteristics and experiences and results in a specific behavior. Cognitive psychology is vital due to its ability to describe difficult behaviors and provided useful foundation for development of Stimulus-Organism-Response (S-O-R) model (Mehrabian \& Russell, 1974).

The current part of the study consists of conceptual framework, S-O-R model of organizational learning and hypotheses development. The core proposition of the 


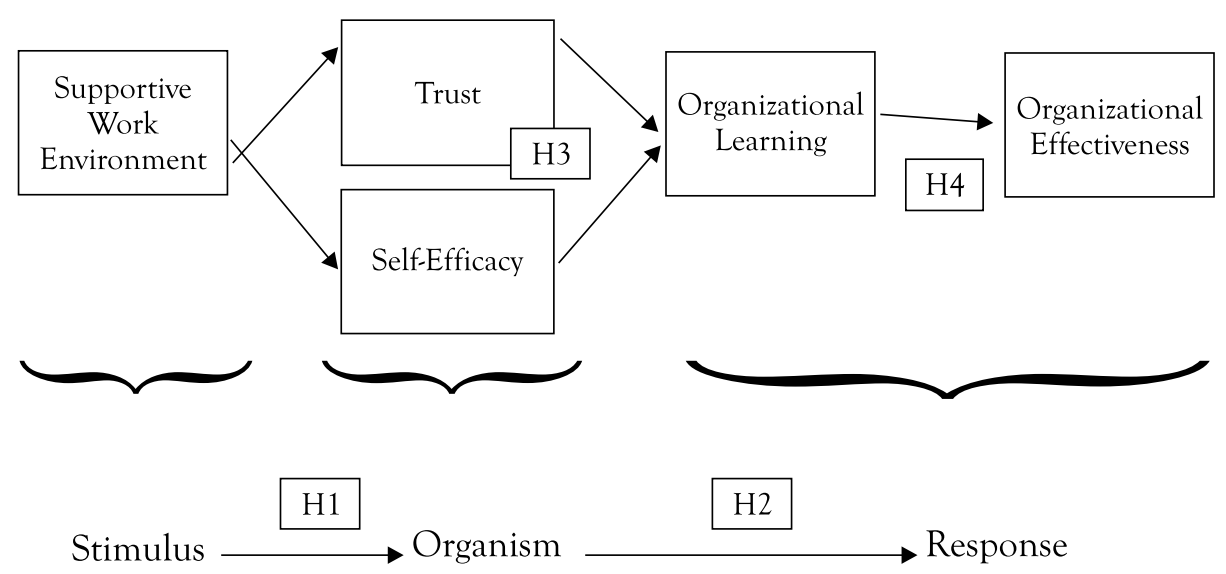

Figure 1: Conceptual framework of organizational learning in term of S-O-R Model

cognitive process is that when person is exposed to a stimulus, he/she develops certain responses that ultimately formulate a specific behavior. Supportive work environment/ external influence act as stimuli variables, whereas employee's psychological factors are organism/intervening variable in the development of organizational learning and learning effectiveness as response. Therefore, according to S-O-R model, only organism acts as mediator. Individual's organizational learning and organizational effectiveness are considered as 'response' variable.

Based on our theoretical framework, stimulus effects organism, and then organism effect response. Furthermore, one response might influence another response. Following hypotheses are formulated to test five main varied paths.

$\mathrm{H}_{1}$ : Relationship between 'Stimulus' and 'Organism'

$\mathrm{H}_{1 \mathrm{a}}$ : Supportive work environment has significant and positive impact on employee's trust.

$\mathrm{H}_{1 \mathrm{~b}}$ : Supportive work environment has significant and positive impact on employee's self-efficacy.

$\mathrm{H}_{2}$ : Relationship between 'Organism' and 'Response'

$\mathrm{H}_{2 \mathrm{a}}:$ Trust has significant and positive impact on organizational learning

$\mathrm{H}_{2 \mathrm{~b}}$ Self-efficacy has significant and positive impact on organizational learning

$\mathrm{H}_{3:}$ Relationship within Organism

$\mathrm{H}_{3:}$ Trust has significant and positive impact on self-efficacy 


\section{$\mathrm{H}_{4:}$ Relationship within Response}

$\mathrm{H}_{4:}$ Organizational learning has significant and positive impact on organizational effectiveness

$\mathrm{H}_{5:}$ Relationship between Stimulus and Response

$\mathrm{H}_{5}$ : Supportive work environment has indirect impact on organizational learning (or organism (i.e. trust and self-efficacy) acts as mediator between stimulus (supportive work environment) and response (organizational learning).

\section{Methodology}

Being a positivist researcher, the current study has used the deductive approach and cross sectional time horizon. On the basis of pre-existing theory, a deductive approach has been established. The study used survey strategy such as questionnaires to collect primary data. Surveys have mostly used in quantitative research along with causal design.

\subsection{Data Collection and Sampling}

Survey is a structured set of questions to measure effects and attributes (Goodwin, 2010) and is a commonly accepted method used in psychological research. Since this research studies attributes and effects data was collected through survey method from employees of banks situated in Islamabad and Rawalpindi which have their own learning and development centers. The convenient sampling technique was used for host of reasons such as expedited data collection and readily available data for the researcher to collect. It also allows for a great ease of research, permitting researchers to focus on analyzing the data rather than interviewing and carefully selecting each participant. One of the most important aspects of this method is its cost effectiveness. Two different approaches have been considered, i.e. suggesting a minimum total sample size such as '400-500 - very good' (Comrey \& Lee, 1992) or examining the ratio of subjects to variables, as in multiple regression, some authors (e.g. Pedhazur, 1997, p. 207) suggest subject to variable ratios of 10:1, 15:1 or 30:1 when generalization is critical. Similarly, rules of thumb for determining adequate sample size $(\mathrm{N})$ are known to be of limited use in achieving an acceptable likelihood for desirable empirical outcomes for a particular application of Confirmatory Factor Analysis (CFA) with real data (Marsh, Hau, Balla, \& Grayson, 1998). Common rules of thumb for determining adequate $\mathrm{N}$ for a particular application of CFA include, but are not limited to: $\mathrm{N} \geq 200$, ratio of $\mathrm{N}$ to the number of variables in a model (p), N/p $\geq 10$ etc. Based on these criteria, a total of 600 employees were contacted, out of which 440 gave their voluntary consent to participate in survey. Finally, 400 
employees' useable data with 41 observed variables $(440 / 41>10)$ was included in study. 5-point Likert scale was used to take responses from employees ranging from $1=$ strongly agree to $5=$ strongly disagree.

\subsection{Measures}

Supportive work environment (SPWE) is the first variable that consists of two dimensions that was studied in this research i.e. management support and co-worker support. Greenhaus, Parasuraman, and Greenhaus, Parasuraman, and Wormley (1990) scale was used to assess the employees' perception regarding this construct. The scales of management support and co-worker support contains 3 items each. The second variable is 'trust' (COGT), two core dimensions of trust was studied i.e. cognitive (cognitive competence, cognitive trust in benevolence, cognitive trust in integrity) and emotional trust. To measure this comprehensive construct of trust, McKnight, Choudhury, and Kacmar (2002) scale was used with 13 items (i.e. 4-items for 'cognitive trust in competence'; 3-items for 'cognitive trust in benevolence'; 4-items for 'cognitive trust in integrity' and 2-items for 'emotional trust').

Table 1: Summary of Scales

\begin{tabular}{|c|c|c|c|}
\hline Variable Code & $\begin{array}{c}\text { No of } \\
\text { Items }\end{array}$ & Author(s) \& Year & Sample Item \\
\hline $\begin{array}{c}\text { Supportive Work Environment } \\
\text { (SPWE) a. Management Support } \\
\text { b. Co-worker Support }\end{array}$ & 03 & $\begin{array}{c}\text { Greenhaus et al. } \\
(1990)\end{array}$ & $\begin{array}{c}\text { Employees in this organization } \\
\text { feel it is easy to approach to } \\
\text { their supervisor. Employees in } \\
\text { this organization trust in their } \\
\text { co-workers }\end{array}$ \\
\hline $\begin{array}{c}\text { Trust (COGT) a. Cognitive Trust } \\
\text { b. Affective Trust }\end{array}$ & 13 & $\begin{array}{c}\text { McKnight et al. } \\
(2002)\end{array}$ & $\begin{array}{c}\text { I feel satisfied being the part } \\
\text { of this organization. I believe } \\
\text { my organization will keep its } \\
\text { commitments }\end{array}$ \\
\hline $\begin{array}{c}\text { Self-Efficacy (SEFF) } \\
\text { Organizational Learning (OLRN) }\end{array}$ & 06 & $\begin{array}{c}\text { Chen, et al. } \\
\text { (2001) }\end{array}$ & $\begin{array}{c}\text { Even when things are tough, I } \\
\text { can perform quite well }\end{array}$ \\
\hline $\begin{array}{c}\text { Organizational Effectiveness } \\
\text { (OEFF) }\end{array}$ & 08 & Liang (2002) & $\begin{array}{c}\text { We promote risk - taking and } \\
\text { experimentation in our working } \\
\text { methods. }\end{array}$ \\
\hline $\begin{array}{c}\text { This is an open organization and } \\
\text { as much information as possible } \\
\text { is made available to employees". }\end{array}$ \\
\hline
\end{tabular}

Whereas, third variable is employee's self-efficacy (SEFF) and to measure this construct Chen, Gully, and Eden (2001) scale was used consisting on 8-items. 
Fourth variable is 'organizational learning' and to measure this construct Spicer and Sadler-Smith (2006) scale was used with 6-items. The last variable is 'organizational effectiveness' or learning effectiveness scales of Liang (2002) was used to measure it with 8-items (see table 1).

\subsection{Statistical Analysis}

Compared to the traditional multivariate method, SEM proffers four advantages (Byrne, 2013) i.e. its concurrent ability to deal with observed and unobserved variables, and precise estimations of parameters of measurement error variance. It also helps analyzing the data for inferential functions by requiring that the inter-relationship patterns should be pre-specified. Moreover, SEM is a comprehensive and unique tool for modeling multivariate relationships and for measurement of direct and indirect effects.

Additionally, Scarpi (2006) noted that SEM applies matrix of variance and co-variances within all the independent and dependent variables. Holmes-Smith (2011) observes that this way SEM application reduces the variation in sample covariance matrix and expected covariance matrix applied by the regression model. Finally, for testing of hypotheses, SEM technique was employed by using AMOS 22.0 through two steps of testing. First, testing of measurement model also known as confirmatory factor analysis (CFA) was used to check the validity and reliability of constructs. Second, structural model test was used to check structural association among exogenous and endogenous variables.

\subsection{Demographic Analysis}

Out of 400 respondents, 277 (69\%) were male and remaining 123 (31\%) were females. On age basis, 212 (59\%) respondents were in age group of 21-30 years. On basis of academic categories. $228(57 \%)$ respondents have education between 15-16 years. Most of the respondents (46\%) had less than 5 years' job experience. At end, 288 (72\%) belonged to middle level job status. To check normality of data for demographic variables, skewness and kurtosis test are also employed which are in acceptable range (Tabachnick, Fidell, \& Osterlind, 2013) (see Table 2).

\section{Analysis and Results}

\subsection{Correlation Analysis}

Correlation analysis is carried out to measure relationship among variables. Results demonstrated positive relation among variables at $p<0.01$. Mean value of variables ranges from 2.05 to 2.35 and standard deviation ranges from 0.64 to 0.71 . 
Table2: Demographic Variable Profile

\begin{tabular}{|c|c|c|c|c|c|}
\hline Variables & Responses & Frequency & Mean (S.D) & Skewness & Kurtosis \\
\hline \multirow{2}{*}{ Gender } & Male & 277 & \multirow{2}{*}{$\begin{array}{c}2 \text { (Mode) } \\
(0.46)\end{array}$} & \multirow{2}{*}{0.90} & \multirow{2}{*}{-.99} \\
\hline & Female & 123 & & & \\
\hline & Less than 20 & 3 & & & \\
\hline \multirow[t]{5}{*}{ Age } & $21-30$ & 212 & \multirow[t]{4}{*}{$2.55(0.81)$} & 1.35 & 1.34 \\
\hline & $31-40$ & 137 & & & \\
\hline & $41-50$ & 32 & & & \\
\hline & Above 50 & 16 & & & \\
\hline & Less than 10 & 18 & & & \\
\hline \multirow[t]{5}{*}{ Education } & $11-12$ & 9 & \multirow[t]{4}{*}{$3.95(0.92)$} & 1.46 & 2.73 \\
\hline & $13-14$ & 45 & & & \\
\hline & $15-16$ & 228 & & & \\
\hline & Above 16 & 100 & & & \\
\hline & Less than 5 & 184 & & & \\
\hline \multirow{5}{*}{$\begin{array}{l}\text { Work Experi- } \\
\text { ence (Overall) }\end{array}$} & $6-10$ & 130 & \multirow[t]{4}{*}{$1.92(1.13)$} & 1.31 & 0.98 \\
\hline & $11-15$ & 41 & & & \\
\hline & $16-20$ & 22 & & & \\
\hline & Above 20 & 23 & & & \\
\hline & Lower level & 79 & & & \\
\hline \multirow[t]{2}{*}{ Job Status } & Middle level & 288 & \multirow[t]{2}{*}{$2(0.51)$} & -0.16 & 0.52 \\
\hline & Upper level & 33 & & & \\
\hline
\end{tabular}

Table 3: Descriptive and Correlation Analysis of Study Variables

\begin{tabular}{|c|c|c|c|c|c|c|c|c|}
\hline & 1 & 2 & 3 & 4 & 5 & M (S.D) & $\begin{array}{c}\text { Skew- } \\
\text { ness }\end{array}$ & Kurtosis \\
\hline SPWE & 1 & & & & & $2.25(0.64)$ & 1.05 & 2.42 \\
\hline SEFF & $.50^{* *}$ & 1 & & & & $2.05(0.65)$ & 1.51 & 4.28 \\
\hline COGT & $.70^{* *}$ & $.58^{* *}$ & 1 & & & $2.19(0.68)$ & 1.24 & 2.48 \\
\hline OLRN & $.65^{* *}$ & $.47^{* *}$ & $.71^{* *}$ & 1 & & $2.35(0.71)$ & 0.57 & 0.67 \\
\hline OEFF & $.73^{* *}$ & $.59^{* *}$ & $.71^{* *}$ & $.60^{* *}$ & 1 & $2.16(0.65)$ & 1.33 & 3.05 \\
\hline
\end{tabular}


For normality, skewness and kurtosis test results are in acceptable range of -3 to +3 (see Table 3).

\subsection{CMV with Harman's Single Factor Test}

To check common method variance and systematic measurement error in survey data, Harman's single-factor test was also applied to establish common method variance (CMV). The results (Table 4) below displays that variance of $1^{\text {st }}$ factor exhibits $37.92 \%$ of total variance which was lesser than standard tolerance limit i.e. $49 \%$. It showed no issue regarding CMV in survey data.

Table 4: Results of CMV analysis (Total Variance Explained)

\begin{tabular}{|c|c|c|c|c|c|c|c|c|c|}
\hline & \multicolumn{3}{|c|}{ Initial Eigenvalues } & \multicolumn{3}{c|}{$\begin{array}{c}\text { Extraction Sums of } \\
\text { Squared Loadings }\end{array}$} & \multicolumn{3}{c|}{$\begin{array}{c}\text { Rotation Sums of Squared } \\
\text { Loadings }\end{array}$} \\
\hline Factor & Total & $\begin{array}{c}\% \text { of } \\
\text { Vari- } \\
\text { ance }\end{array}$ & $\begin{array}{c}\text { Cumu- } \\
\text { lative } \\
\%\end{array}$ & Total & $\begin{array}{c}\% \text { of } \\
\text { Vari- } \\
\text { ance }\end{array}$ & $\begin{array}{c}\text { Cumu- } \\
\text { lative } \\
\%\end{array}$ & $\begin{array}{c}\text { Total } \\
\% \text { of } \\
\text { Vari- } \\
\text { ance }\end{array}$ & $\begin{array}{c}\text { Cumu- } \\
\text { lative } \\
\%\end{array}$ \\
\hline 1 & 16.68 & 37.92 & 37.92 & 16.21 & 36.85 & 36.85 & 4.85 & 11.03 & 11.03 \\
\hline & & & & & & & & \multicolumn{2}{|c|}{$\begin{array}{c}\text { Total Variance } \\
53.80\end{array}$} \\
\hline
\end{tabular}

\subsection{Testing of Measurement Model}

In measurement model, confirmatory factor analysis (CFA) was performed. The assessment of factor loading (FL) and squared-multiple-correlation (SMC) was used to measure item's reliability and to identify the problematic observed errors. If the value of FL is below 0.50 coupled with SMC values lower than 0.20 of an item then that item is omitted as per the criteria (Hu \& Bentler, 1999). 4-items of supportive work environment were eradicated out of 9-items due to low FL and SMC. Similarly, all remaining observed variables were eradicated due to low FL and SMC (see Table 4).

Goodness of model fit also presented satisfactory results of indices i.e. CMIN/DF $=2.50 ; \mathrm{GFI}=0.88 ; \mathrm{AGFI}=0.82 ; \mathrm{CFI}=0.91 ; \mathrm{RMSEA}=0.06$. Measurement model also presented the additional convergent reliability qualities (Fornell \& Larcker, 1981). Cronbach's alpha or internal consistency (IC) ranged between 0.80-0.91, Composite reliability (CR) ranged 0.78-0.91 and Average Variance Extracted (AVE) ranged 0.470.53 . Whereas, $R^{2}$ values are explaining variability of responses about their means.

\subsection{Multicollinearity}

For multicollinearity, variance inflation factor (VIF) and tolerance tests were employed on all studied variables with organizational learning and organizational 
Table 5: Verification of Convergent Validity

\begin{tabular}{|c|c|c|c|c|c|}
\hline $\begin{array}{l}\text { Latent Vari- } \\
\text { ables }\end{array}$ & Observed Variables & St. FL & IC & $\mathrm{CR}$ & AVE \\
\hline SWE (5 items) & Spe1, spe2, spe3, spe4, spe 5 & $.76, .74, .71, .77, .62$ & 0.84 & 0.84 & 0.52 \\
\hline $\begin{array}{l}\text { TRUST (9 } \\
\text { items) }\end{array}$ & $\begin{array}{l}\text { Cogti1, Cogti2, Cogti3, Cog- } \\
\text { ti4, Cogtb1, Cogtb2, Cogtb3, } \\
\text { Cogte1, Cogte } 2\end{array}$ & $\begin{array}{c}.72, .76, .80, .73 \\
.65, .71, .71, .77, .72\end{array}$ & 0.91 & 0.91 & 0.53 \\
\hline SEFF (6 items) & $\begin{array}{c}\text { Seff1, Seff2, Seff3, Seff5, } \\
\text { Seff7, Seff8 }\end{array}$ & $\begin{array}{c}.72, .76, .73, .70 \\
.72, .68\end{array}$ & 0.85 & 0.86 & 0.52 \\
\hline $\begin{array}{l}\text { OLRN }(4 \\
\text { items) }\end{array}$ & OL1, OL2, OL3, OL4 & $.70, .67, .64, .73$ & 0.80 & 0.78 & 0.47 \\
\hline ORG (7 items) & $\begin{array}{l}\text { Orgef2, Orgef4, Orgef5, } \\
\text { Orgef6, Orgef7, Orgef8 }\end{array}$ & $\begin{array}{c}.67, .72, .70, .77 \\
.74, .75\end{array}$ & 0.84 & 0.87 & 0.53 \\
\hline
\end{tabular}

effectiveness separately. Results represented no issue of multicollinearity as VIF values are less than 10 and tolerance values are above 0.10 (see Table 6) recommended by O'brien (2007). Prior to the analysis of structural model, multicollinearity issues were also checked.

Table 6: Multicollinearity Analysis

\begin{tabular}{|c|c|c|c|c|}
\hline & \multicolumn{5}{|c|}{ Collinearity Statistics } \\
\hline & OLRN1 & OEFF2 & OLRN1 & OEFF2 \\
\hline $\begin{array}{c}\text { SPWE (Support- } \\
\text { ive work environ- } \\
\text { ment) }\end{array}$ & 0.50 & 0.46 & 1.99 & 2.16 \\
\hline $\begin{array}{c}\text { SEFF (Self-effi- } \\
\text { cacy) }\end{array}$ & 0.64 & 0.64 & 1.57 & 1.58 \\
\hline $\begin{array}{c}\text { COGT (Cogni- } \\
\text { tive Trust) }\end{array}$ & 0.44 & 0.35 & 2.25 & 2.79 \\
\hline $\begin{array}{c}\text { OLRN (Organiza- } \\
\text { tional Learning) }\end{array}$ & - & 0.45 & - & 2.24 \\
\hline
\end{tabular}

1. OLRN (Dependent variable)

2. OEFF (Dependent variable)

\subsection{Testing of Structural Model}

Structural model comprised of five unobserved/latent variables with thirty-two observed variables. 


\subsubsection{Direct effects}

In structural model analysis, according to hypothesis 1 (Stimulus $\rightarrow$ Organism), the value of standardized regression $\left(\mathrm{H}_{1}: \gamma=0.86, \mathrm{p}<0.01\right)$ indicated a significant positive and strong relationship between supportive-work-environment and trust. Whereas, there was insignificant relationship between supportive-work-environment and self-efficacy. According to hypothesis 2 (Organism $\rightarrow$ Response), significant relation exists between trust and organizational learning $\left(\mathrm{H}_{2:}: \gamma=0.54, \mathrm{p}<0.01\right)$, as well as relation exist between self-efficacy and organizational learning $\left(\mathrm{H}_{2 \mathrm{~b}}: \gamma=0.14\right.$, $\mathrm{p}<0.01$ ). In hypothesis 3 (Organism $\rightarrow$ Organism), relationship exist between trust and self-efficacy $\left(\mathrm{H}_{3}: \gamma=0.62, \mathrm{p}<0.01\right)$. Similarly, significant relation exists between organizational learning and organizational effectiveness $\left(\mathrm{H}_{4}: \gamma=0.83, \mathrm{p}<0.01\right)$ in hypothesis 4 (Response $\rightarrow$ Response).

\subsubsection{Indirect effects}

According to hypothesis 5, significant indirect relationship exists between supportive-work-environment and organizational learning. The study follows the Preacher and Hayes's (2008) propositions with bootstrapping of 5000 to observe the mediations to avoid the measurement error that may occur with SEM. The results show all the direct and indirect effects are significant with $(\mathrm{P}<0.01)$. Further, results show standardized indirect effect (.54), standard error (.16) with 95\% - Two Tailed Significance (BC) at $\mathrm{p}$-value $(0.01)$ propose the hypothesized relations appeared to be true and the results indicate significant mediation of trust between supportive work environment (as IVs) and organizational learning (as DV). On the other-side, self-efficacy does not act as a mediator between supportive work environment and organizational learning because of insignificant relation between supportive work environment and self-efficacy.

For structural model, goodness of model fit indices was also examined which showed satisfactory results i.e. $\mathrm{CMIN} / \mathrm{DF}=2.41 ; \mathrm{GFI}=0.90 ; \mathrm{AGFI}=0.83 ; \mathrm{CFI}=$ $0.91 ;$ RMSEA $=0.06$.

\section{Conclusion}

This study has endeavored to explore the influence of supportive work environment, trust and self-efficacy on organizational learning and its effectiveness theoretically as well as empirically. Results revealed the significant impact of supportive work environment on employee's psychological trait like attributes i.e. trust and self-efficacy. The results are consistent with the study performed by Mutahi and Busienei (2015), thus, it suggests the need for supportive work environment (Hammer, Kossek, Anger, Bodner, \& Zimmerman, 2011) for tolerant and supportive culture that recognizes the benefit for employees. In nutshell, management and coworker support result into a 
conducive work environment whereby individuals develop a capability to learn and contribute to the organizational effectiveness. Role of supportive work environment in affecting trust and efficacy, as revealed in the results of current study, has important implications. First, these results validate the commonly held belief that supportive work environment has consequences that are beneficial for organizations. Second, it provides a way forward to understand the significance and the need to employ management and peer support both to create supportive work environment in organizations. Third, individual psychological responses to such an environment, in their self, could be very much desirable individual attributes (i.e. trust and efficacy) hungrily sought by organizations since times. Thus, this study provides a focus avenue (i.e. creating a supportive work environment) to decision makers for building trust and subsequently nurturing self-efficacy of employees. Consistent with the results of Chen and Huang (2007), our analysis verified the relation of trust and organizational learning. Reasons for positive relationship between trust and organizational learning can be ascribed to several factors which may include recognition, involvement of employees, listening to employees as well as customer's ideas and also acted upon.

One of the interesting contributions of current study is that it explains the ways through which trust directly and indirectly cherishes organizational learning and organizational effectiveness. On one side, trust plays an important role in building self-efficacy and subsequently affects organizational learning. On the other side, trust directly contributes to organizational effectiveness. These findings signify the importance of building trust in organizations and its positive consequences. With employees holding trust, give them confidence to engage in endeavors of new learning and knowledge exchange thus creating lot more possibilities of organizational learning and subsequently affecting organizational performance.., Similarly, coworkers or colleagues, due to supportive work environment, also help in learning by sharing their knowledge and expertise, especially when an individual faces difficulty or get involve in novel task for which a solution is not readily available (Scott \& Bruce, 1994). Hence, similar to the findings Rhoades and Eisenberger (2002), employee's involvement in free and open discussion of ideas, facilitated by supportive work environment, help in the development of organizational learning.

\subsection{Limitations and Recommendations}

The current research is cross-sectional; a longitudinal study is needed to gauge the relationship of trust, self-efficacy, organizational learning and its effectiveness. The sample size 400 with non-random sampling technique taken for the study is not large enough to reflect the accurate and realistic image of the organizations operating in Pakistan. The study particularly focused on employees from selected banks, further 
research can be expanded to other banks which were not part of the study. Employee's views regarding organizational leaning can be studied by conducting future research on personality trait behind trust development as well as other sectors too. Specifically, it could be worthwhile to conduct a series of case studies in different sectors of the economy that evaluate the separate effects of management support and peer support in building trust and self-efficacy. Such case studies might help us understand the relative importance of different types of supports that create a supportive work environment in specific contexts. Similarly, the separate effects of cognitive and emotional trust on organizational outcomes could improve our understanding of the ways trust is beneficial. Furthermore, the mechanism through which self-efficacy affects organizational learning needs to be further explained.

\section{References}

AbuAlRub, R. F., Al-Akour, N. A., \& Alatari, N. H. (2015). Perceptions of reporting practices and barriers to reporting incidents among registered nurses and physicians in accredited and nonaccredited Jordanian hospitals. Journal of Clinical Nursing, 24(20), 2973-2982.

Afzali, A., Arash Motahari, A., \& Hatami-Shirkouhi, L. (2014). Investigating the influence of perceived organizational support, psychological empowerment and organizational learning on job performance: An empirical investigation. Tehnički vjesnik, 21(3), 623-629.

Alaei, A., Shafaee, J., Ariana, A., \& Maghvan, T. (2012). The role of knowledge management in created organizational innovation. Journal of Basic and Applied Scientific Research, 2(2), 1136-1141

Amabile, T. M. (1983). The social psychology of creativity: A componential conceptualization. Journal of Personality and Social Psychology, 45(2), 357-376.

Anbar, A., \& Eker, M. (2016). An examination of relationship between burnout and job satisfaction among Turkish accounting and finance academicians. European Journal of Economic and Political Studies, 1(1), 39-57.

Anderson, N., Potočnik, K., \& Zhou, J. (2014). Innovation and creativity in organizations a state-ofthe-science review, prospective commentary, and guiding framework. Journal of Management, 40(5), 1297-1333.

Argote, L. (2012). Organizational learning: Creating, retaining and transferring knowledge: Springer Science $\&$ Business Media.

Arnold, K. A., \& Dupré, K. E. (2012). Perceived organizational support, employee health and emotions. International Journal of Workplace Health Management, 5(2), 139-152

Atak, M., \& Erturgut, R. (2010). An empirical analysis on the relation between learning organization and organizational commitment. Procedia-Social and Behavioral Sciences, 2(2), 3472-3476 
Bandura, A. (1986). The explanatory and predictive scope of self-efficacy theory. Journal of Social and Clinical Psychology, 4(3), 359-373

Bates, R., Kauffeld, S., \& Holton III, E. F. (2007). Examining the factor structure and predictive ability of the German-version of the Learning Transfer Systems Inventory. Journal of European Industrial Training, 31(3), 195-211.

Bates, R. A., Holton, E. F., \& Hatala, J. P. (2012). A revised learning transfer system inventory: Factorial replication and validation. Human Resource Development International, 15(5), 549-569.

Birdi, K. (2007). A lighthouse in the desert? Evaluating the effects of creativity training on employee innovation. The Journal of Creative Behavior, 41(4), 249-270.

Birdi, K., Leach, D., \& Magadley, W. (2012). Evaluating the impact of TRIZ creativity training: An organizational field study. $R$ E D Management, 42(4), 315-326.

Birdi, K., Leach, D., \& Magadley, W. (2016). The relationship of individual capabilities and environmental support with different facets of designers' innovative behavior. Journal of Product Innovation Management, 33(1), 19-35.

Blume, B. D., Ford, J. K., Baldwin, T. T., \& Huang, J. L. (2010). Transfer of training: A meta-analytic review. Journal of Management, 36(4), 1065-1105.

Broad, M. L., \& Newstrom, J. W. (1992). Transfer of training: Action-packed strategies to ensure high payoff from training investments: ERIC.

Byrne, B. M. (2001). Structural equation modeling with AMOS: Basic concepts, applications, and programming: Lawrence Erlbaum Associates Inc.: Mahwah, NJ.

Cameron, K. (1978). Measuring organizational effectiveness in institutions of higher education. Administrative Science Quarterly, 23, 604-632.

Charkhabi, M., Abarghuei, M. A., \& Hayati, D. (2013). The association of academic burnout with self-efficacy and quality of learning experience among Iranian students. Springerplus, 2(1), 677-681.

Chauhan, R., Ghosh, P., Rai, A., \& Shukla, D. (2016). The impact of support at the workplace on transfer of training: A study of an Indian manufacturing unit. International Journal of Training and Development, 20(3), 200-213.

Chen, C.-J., \& Huang, J.-W. (2007). How organizational climate and structure affect knowledge management-The social interaction perspective. International Journal of Information Management, 27(2), 104-118.

Chen, G., Gully, S. M., \& Eden, D. (2001). Validation of a new general self-efficacy scale. Organizational Research Methods, 4(1), 62-83.

Chiaburu, D. S., Van Dam, K., \& Hutchins, H. M. (2010). Social support in the workplace and training transfer: A longitudinal analysis. International Journal of Selection and Assessment, 18(2), 187-200. 
Choi, J. N., \& Chang, J. Y. (2009). Innovation implementation in the public sector: an integration of institutional and collective dynamics. Journal of Applied Psychology, 94(1), 245-253.

Chowdhury, S. (2005). The role of affect-and cognition-based trust in complex knowledge sharing. Journal of Managerial Issues, 17 , 310-326.

Çokpekin, Ö., \& Knudsen, M. P. (2012). Does organizing for creativity really lead to innovation? Creativity and Innovation Management, 21(3), 304-314.

Comrey, A., \& Lee, H. (1992). A first course in factor analysis ( $2^{\text {nd }}$ ed.) Lawrence Earlbaum Associates. Hillsdale, NJ.

Curado, C. (2006). Organisational learning and organisational design. The Learning Organization, 13(1), $25-48$

Goodwin, C. J. (2010). Research in psychology: Methods and design. Hoboken, NJ: John Wiley \& Sons

Dermol, V., \& Cater, T. (2013). The influence of training and training transfer factors on organisational learning and performance. Personnel Review, 42(3), 324-348.

Edwards, M. T. (2016). An Organizational Learning Framework for Patient Safety. American Journal of Medical Quality, 32(2), 1-8

Egan, T. M., Yang, B., \& Bartlett, K. R. (2004). The effects of organizational learning culture and job satisfaction on motivation to transfer learning and turnover intention. Human Resource Development Quarterly, 15(3), 279-301

Evanschitzky, H., Eisend, M., Calantone, R. J., \& Jiang, Y. (2012). Success factors of product innovation: An updated meta-analysis. Journal of Product Innovation Management, 29(S1), 21-37.

Fallatah, F., \& Laschinger, H. K. (2016). The influence of authentic leadership and supportive professional practice environments on new graduate nurses' job satisfaction. Journal of Research in Nursing, 47(3), 363-385.

Findikli, M. A., Gulden, A. \& Semercioz, F. (2010), Subordinate trust in supervisor and organization: Effects on subordinate perceptions of psychological empowerment. International Journal of Business and Management Studies, 2(1), 55-67.

Fiol, C. M., \& Lyles, M. A. (1985). Organizational learning. Academy of Management Review, 10(4), 803-813.

Fornell, C., \& Larcker, D. F. (1981). Structural equation models with unobservable variables and measurement error: Algebra and statistics. Journal of Marketing Research, 18, 382-388.

Furedy, J. J., \& Riley, D. M. (1987). Human Pavlovian autonomic conditioning and the cognitive paradigm. In G. Davey (Ed.), Cognitive processes and pavlovian conditioning in humans. (pp. 1-25). New York: Wiley \& Sons.

Garvin, D. A. (1993). Building a learning organization. Harvard business review, 71(4), 78-91. 
Gilson, C., Dunleavy, P., \& Tinkler, J. (2009). Organizational learning in government sector organizations: Literature review. LSE Public Policy Group, London School of Economics and Political Science, London, UK

Goyal, S., \& Chhabra, N. (2015). Benefits of employee training for developing economy. Global Journal For Research Analysis, 4(10), 18-20.

Greenhaus, J. H., Parasuraman, S., \& Wormley, W. M. (1990). Effects of race on organizational experiences, job performance evaluations, and career outcomes. Academy of Management Journal, 33(1), 64-86.

Greenhaus, J. H., Ziegert, J. C., \& Allen, T. D. (2012). When family-supportive supervision matters: Relations between multiple sources of support and work-family balance. Journal of Vocational Behavior, 80(2), 266-275.

Hammer, L. B., Kossek, E. E., Anger, W. K., Bodner, T., \& Zimmerman, K. L. (2011). Clarifying workfamily intervention processes: The roles of work-family conflict and family-supportive supervisor behaviors. Journal of Applied Psychology, 96(1), 134-150.

Hawley, J. D., \& Barnard, J. K. (2005). Work environment characteristics and implications for training transfer: A case study of the nuclear power industry. Human Resource Development International, $8(1), 65-80$.

Hayati, D., Charkhabi, M., \& Naami, A. (2014). The relationship between transformational leadership and work engagement in governmental hospitals nurses: a survey study. SpringerPlus, 3(1), 25-32.

Hines, J. T. (2008). Making Collaboration Work in Inclusive High School Classrooms Recommendations for Principals. Intervention in School and Clinic, 43(5), 277-282.

Hinno, S. (2012). The professional practice environment hospital nurses' perspectives in three European countries. Dissertations in Health Sciences, 107, 1798-5714.

Hirsch, P. M. (1975). Organizational effectiveness and the institutional environment. Administrative Science Quarterly, 20, 327-344.

Holmes-Smith, P. (2011). Advanced structural equation modelling using AMOS. Paper presented the Workshop material provided at the ACSPRI.

Holton, E., Bates, R. A., \& Ruona, W. E. (2000). Development of a generalized learning transfer system inventory. Human Resource Development Quarterly, 11(4), 333-360.

Homklin, T., Takahashi, Y., \& Techakanont, K. (2014). The influence of social and organizational support on transfer of training: Evidence from Thailand. International Journal of Training and Development, 18(2), 116-131.

Hu, L. t., \& Bentler, P. M. (1999). Cutoff criteria for fit indexes in covariance structure analysis: Conventional criteria versus new alternatives. Structural Equation Modeling: A Multidisciplinary Journal, 6(1), $1-55$. 
Huber, G. P. (1991). Organizational learning: The contributing processes and the literatures. Organization Science, 2(1), 88-115.

Hui, C., Lee, C. \& Rousseau, D. M. (2004). Employment relationships in China: Do workers relate to the organization or to people? Organization Science, 15(2), 232-240.

Hunt, J. S., Gibson, R. F., Whittington, J., Powell, K., Wozney, B., \& Knudson, S. (2015). Guide for developing an information technology investment road map for population health management. Population Health Management, 18(3), 159-171.

Kamena, G., \& Potter, A. R. (2016). The Emotional Constructs of Trust: A Practical Approach. The Journal of Character $\mathcal{E}$ Leadership Integration, Special Issue, 42-49.

Karatepe, O. M. (2012). Perceived organizational support, career satisfaction, and performance outcomes: a study of hotel employees in Cameroon. International Journal of Contemporary Hospitality Management, 24(5), 735-752.

Karatepe, O. M. (2015). Do personal resources mediate the effect of perceived organizational support on emotional exhaustion and job outcomes? International Journal of Contemporary Hospitality Management, 27(1), 4-26.

Karatepe, O. M. (2016). Does job embeddedness mediate the effects of coworker and family support on creative performance? An empirical study in the hotel industry. Journal of Human Resources in Hospitality $\mathcal{E}$ Tourism, 15(2), 119-132.

Karatepe, O. M., \& Agbaim, I. M. (2012). Perceived ethical climate and hotel employee outcomes: an empirical investigation in Nigeria. Journal of Quality Assurance in Hospitality $\mathcal{E}$ Tourism, 13(4), 286-315.

Karatepe, O. M., \& Vatankhah, S. (2014). The Effects of High-Performance Work Practices on Perceived Organizational Support and Turnover Intentions: Evidence from the Airline Industry. Journal of Human Resources in Hospitality EO Tourism, 13(2), 103-119.

King, W. R. (2009). Knowledge management and organizational learning: Springer.

Kirwan, M., Matthews, A., \& Scott, P. A. (2013). The impact of the work environment of nurses on patient safety outcomes: a multi-level modelling approach. International Journal of Nursing Studies, 50(2), 253-263.

Kottke, J. L., \& Sharafinski, C. E. (1988). Measuring perceived supervisory and organizational support. Educational and Psychological Measurement, 48(4), 1075-1079

Kramer, M., \& Schmalenberg, C. (2003). Securing "good” nurse/physician relationships. Nursing Management, 34(7), 34-38.

Kutney-Lee, A., Wu, E. S., Sloane, D. M., \& Aiken, L. H. (2013). Changes in hospital nurse work environments and nurse job outcomes: an analysis of panel data. International Journal of Nursing Studies, 50(2), 195-201. 
Lapré, M. A. Nembhard. 2010. Inside the Organizational Learning Curve: Understanding the Organizational Learning Process. Foundations and Trends $R$ in Technology, Information and Operations Management, 4(1), 1-103.

Lau, P. Y. Y., \& McLean, G. N. (2013). Factors influencing perceived learning transfer of an outdoor management development programme in Malaysia. Human Resource Development International, 16(2), 186-204.

Levin, D. Z., \& Cross, R. (2004). The strength of weak ties you can trust: The mediating role of trust in effective knowledge transfer. Management Science, 50(11), 1477-1490.

Liang, C. (2002). An investigation of factors influencing online learning effectiveness. National Pintung University of Science and Technology, Pingtung, Taiwan.

Loermans, J. (2002). Synergizing the learning organization and knowledge management. Journal of Knowledge Management, 6(3), 285-294.

Lu, X. (2014). Ethical leadership and organizational citizenship behavior: The mediating roles of cognitive and affective trust. Social Behavior and Personality: An International Journal, 42(3), 379-389.

Lunenburg, F. C. (2011). Self-efficacy in the workplace: Implications for motivation and performance. International Journal of Management, Business, and Administration, 14(1), 1-6.

Luthans, F. (1998). Organisational behaviour ( $8^{\text {th }}$ ed.). Boston, MA: Irwin, McGraw-Hill.

Mache, S., Vitzthum, K., Wanke, E., David, A., Klapp, B. F., \& Danzer, G. (2014). Exploring the impact of resilience, self-efficacy, optimism and organizational resources on work engagement. Work, 47(4), 491-500.

Madjar, N. (2008). Emotional and informational support from different sources and employee creativity. Journal of Occupational and Organizational Psychology, 81(1), 83-100.

Manojlovich, M. (2005). Promoting Nurses' Self-efficacy: A Leadership Strategy to Improve Practice. Journal of Nursing Administration, 35(5), 271-278

Marsh, H. W., Hau, K.-T., Balla, J. R., \& Grayson, D. (1998). Is more ever too much? The number of indicators per factor in confirmatory factor analysis. Multivariate Behavioral Research, 33(2), 181-220.

Martin, H. J. (2010). Workplace climate and peer support as determinants of training transfer. Human Resource Development Quarterly, 21(1), 87-104.

Martinez, L. F., \& Zeelenberg, M. (2015). Trust me (or not): Regret and disappointment in experimental economic games. Decision, 2(2), 118-126.

McEvily, B., \& Tortoriello, M. (2011). Measuring trust in organisational research: Review and recommendations. Journal of Trust Research, 1(1), 23-63

McKnight, D. H., Choudhury, V., \& Kacmar, C. (2002). Developing and validating trust measures for 
e-commerce: An integrative typology. Information Systems Research, 13(3), 334-359.

Mehrabian, A., \& Russell, J. A. (1974). An approach to environmental psychology: The MIT Press.

Messersmith, J. G., Patel, P. C., Lepak, D. P., \& Gould-Williams, J. S. (2011). Unlocking the black box: Exploring the link between high-performance work systems and performance. Journal of Applied Psychology, 96(6), 1105-18.

Miao, R.-T. (2011). Perceived organizational support, job satisfaction, task performance and organizational citizenship behavior in China. Journal of Behavioral and Applied Management, 12(2), 105-127.

Miller, N. E., \& Dollard, J. (1941). Social learning and imitation. New Haven, Connecticut: Yale University Press.

Morgen, S. D. (1997). Selling with integrity: Reinventing sales through collaboration, respect, and serving. San Francisco, CA: Berrett-Koehler Publishers.

Mutahi, N., \& Busienei, J. R. (2015). Effect of human resource management practices on performance of public universities in kenya. International Journal of Economics, Commerce and Management, 3(10), 696-735.

Nembhard, I. M., Cherian, P., \& Bradley, E. H. (2014). Deliberate learning in health care the effect of importing best practices and creative problem solving on hospital performance improvement. Medical Care Research and Review, 71(5), 450-471.

Nembhard, I. M., \& Tucker, A. L. (2016). Applying organizational learning research to accountable care organizations. Medical Care Research and Review, 73 (6), 673-684.

Noe, R. A. (1986). Trainee attributes and attitudes: Neglected influences of training effectiveness. Academy of Management Review, 11, 736-749.

O'brien, R. M. (2007). A caution regarding rules of thumb for variance inflation factors. Quality $\mathcal{E}$ Quantity, 41(5), 673-690.

Oh, I. S., Guay, R. P., Kim, K., Harold, C. M., Lee, J. H., Heo, C. G., \& Shin, K. H. (2014). Fit happens globally: A meta-analytic comparison of the relationships of person-environment fit dimensions with work attitudes and performance across East Asia, Europe, and North America. Personnel Psychology, 67(1), 99-152.

Ohme, M., \& Zacher, H. (2015). Job performance ratings: The relative importance of mental ability, conscientiousness, and career adaptability. Journal of Vocational Behavior, 87, 161-170.

Pedhazur, E. J. (1997). Multiple regression in behavioral research (3 ${ }^{\text {rd }}$ ed.). Orlando, FL: Harcourt Brace.

Preacher, K. J., \& Hayes, A. F. (2008). Asymptotic and resampling strategies for assessing and comparing indirect effects in multiple mediator models. Behavior research methods, 40(3), 879-891.

Reina, D. S., \& Reina, M. L. (2006). Trust $\mathcal{E}$ betrayal in the workplace: Building effective relationships in your 
organization: Berrett-Koehler Publishers.

Rhoades, L., \& Eisenberger, R. (2002). Perceived organizational support: A review of the literature. Journal of Applied Psychology, 87(4), 698-714

Rousseau, D. M., Sitkin, S. B., Burt, R. S., \& Camerer, C. (1998). Not so different after all: A cross-discipline view of trust. Academy of Management Review, 23(3), 393-404.

Russ-Eft, D. (2002). A typology of training design and work environment factors affecting workplace learning and transfer. Human Resource Development Review, 1(1), 45-65.

Russo, M., Shteigman, A., \& Carneli, A. (2015). Workplace and family support and work-life balance: Implications for individual psychological availability and energy at work. The Journal of Positive Psychology, 11(12), 173-188.

Saks, A. M. (2006). Antecedents and consequences of employee engagement. Journal of Managerial Psychology, 21(7), 600-619.

Salanova, M., Llorens, S., \& Schaufeli, W. B. (2011). "Yes, I can, I feel good, and I just do it!” On gain cycles and spirals of efficacy beliefs, affect, and engagement. Applied Psychology, 60(2), 255-285.

Scarbrough, H., Swan, J., \& Preston, J. (1999). Knowledge management and the learning organization. The IPD Report. Institute of Personnel Development, London.

Scarpi, D. (2006). Fashion stores between fun and usefulness. Journal of Fashion Marketing and Management: An International Journal, 10(1), 7-24.

Schwartz, T., \& McCarthy, C. (2007). Manage your energy, not your time. Harvard Business Review, $85(10), 63-72$.

Scott, S. and Bruce, R. (1994). Determinants of innovative behavior: A path model of individual innovation in the workplace. The Academy of Management Journal, 37, 580-607.

Shafritz, J., \& Ott, J. (2001). Classics of organisational theory. Fort Worth: Harcourt College Publishers.

Shantz, A. and Latham, G. P. (2012). Transfer of training: written self-guidance to increase self-efficacy and interviewing performance of job seekers. Human Resource Management, 51(5), 733-46.

Soni, S .S (2013). Employee engagement - A key to organisational success in the $21^{\text {st }}$ century. Voice of Research, 1(4), 49-79.

Spicer, D. P., \& Sadler-Smith, E. (2006). Organizational learning in smaller manufacturing firms. International Small Business Journal, 24(2), 133-158.

Tabachnick, B. G., Fidell, L. S., \& Osterlind, S. J. (2013). Using multivariate statistics (6 $6^{\text {th }}$ ed.). Boston: Pearson.

Tierney, P., \& Farmer, S. M. (2002). Creative self-efficacy: Its potential antecedents and relationship to creative performance. Academy of Management Journal, 45(6), 1137-1148. 
Tsai, Chao-Wen., Tsai, Shieunt-Han., Chen, Ying-Ying., \& Lee, Wei-Lun. (2014). A study of nursing competency, career self-efficacy and professional commitment among nurses in Taiwan. Contemporary Nurse, 49(1), 96-102.

Unger-Aviram, E., \& Erez, M. (2016). The effects of situational goal orientation and cultural learning values on team performance and adaptation to change. European Journal of Work and Organizational Psychology, 25(2), 239-253.

Wallace, E., de Chernatony, L., \& Buil, I. (2011). Within-role, extra-role and anti-role behaviours in retail banking. International Journal of Bank Marketing, 29(6), 470-488.

Wei Tian, A., Cordery, J., \& Gamble, J. (2016). Returning the favor: positive employee responses to supervisor and peer support for training transfer. International Journal of Training and Development, 20(1), $1-16$.

Yavas, U., \& Benkenstein, M. (2007). Service quality assessment: a comparison of Turkish and German bank customers. Cross Cultural Management: An International Journal, 14(2), 161-168. 